\title{
The Reporting and Sustainable Business Marketing
}

\author{
Ionel Jianu ${ }^{1, *}$, Carmen Ţurlea ${ }^{2,+}$ and Ionela Guşatu ${ }^{3,+}$ \\ Received: 19 September 2015; Accepted: 21 December 2015; Published: 29 December 2015 \\ Academic Editor: Giuseppe Ioppolo \\ 1 Department of Accounting and Audit, Faculty of Accounting and Management Information Systems, \\ The Bucharest University of Economic Studies, 6 PiaţaRomană, District 1, Bucharest 010374, Romania \\ 2 Department of Management, Faculty of Management, The Bucharest University of Economic Studies, \\ 6 PiaţaRomană, District 1, Bucharest 010374, Romania; carmen.turlea@man.ase.ro \\ 3 Department of Modern Languages, "Carol Davila" University of Medicine and Pharmacy, \\ 8 Bld. Eroii Sanitari, Bucharest 050474, Romania; yonela_g2001@yahoo.com \\ * Correspondence: ionel.jianu@cig.ase.ro; Tel.: +40-72-450-8501 \\ + These authors contributed equally to this work.
}

\begin{abstract}
Companies have to communicate to be noticed on the market, to promote their services and products, and to give assurances that they are a credible partner in the relationship with stakeholders. In this article, starting from the importance of marketing communication in business, an index of sustainability communication was created for the companies listed on the Bucharest Stock Exchange for the period 2008-2009, during the financial crisis, seeking to show the awareness of the difficult moment and the use of communication. Then, based on the relevance of accounting information model, we study the relationship between the index of sustainability communication and the share price, basically its influence on the future performance of the company. The regression analysis emphasizes the positive influence of the index of sustainability communication on the share price.
\end{abstract}

Keywords: sustainable development; sustainability communication; marketing campaign; accounting and financial reporting

\section{Introduction}

In this research, we aim to explain the "whole" that is obtained by term association (marketing and reporting) in business sustainability, to show that their unity is achieved by "communication", and to demonstrate that sustainability, in terms of marketing and reporting, positively influences the performance of companies. With regard to marketing, the practical theory is that which can support the current research approach, namely creating value through marketing actions [1]. This allows us to consider marketing as both infrastructure and tools that are available to the company for the achievement of the aimed performance objectives.

The social and environmental impact of human actions has become a subject of analysis and discussion for both academics and practitioners [2]. Companies tend to be more and more aware of and responsible for the impact of the activities they carry out on society and the environment. Consequently, sustainable development, as a principle of the economic entity, tends to have a central position in the policies pursued by and in connection with the company [3]. Researches undertaken on sustainability devote large spaces and promote the link between social and environmental issues $[4,5]$.

This paper aims to show that, by communication (which is specific to both marketing and sustainability reporting), the company achieves its performance objectives. Thus, the reported information and the marketing message are delivered by stakeholders, together they act and create added value for the company. Sustainability and marketing reports help to strengthen the market 
position of the company, to make it noticed and involved in campaigns with social effects and environmental protection.

Business sustainability is a goal promoted by companies and sought to be achieved by them using the business strategy [6]. The strategy, structure, and performance (SSP) model can be applied to show how sustainable strategy leads to the desired results [7]. Sustainable development, in terms of conceptual and practical realization approach, evolved from "meeting the present needs without compromising the ability of future generations to meet their own needs" [8] towards a sustainability framework based on three pillars—environmental, economic, and social—which are united in what is called the "triple bottom line". Many models, including the holistic model of corporate responsibility [9], which integrates multiple values of sustainability, and also the mathematical model for calculating a composite index for sustainable development [10], contributed to the study of this concept in the field's literature.

The company's actions aiming to promote the stakeholders' needs have been known for a long time by those who want success in business. The stakeholder becomes increasingly important for the economic entity, being a partner of the economic entity, an agent promoting the company's image and, thus, an important cogwheel of any business management mechanism. Moreover, the stakeholders' theory will support the entire approach we propose in order to highlight the importance of communication for the sustainable development of the company. Amid the diversification provided, and the procedures for questioning in relation to social responsibility, it starts to be increasingly difficult for external stakeholders to assess the sustainable performance of economic entities. To reduce the information asymmetry between the company and its stakeholders, commercial entities have to communicate in terms of responsible behaviour and to comply with the transparency requirements of business sustainability [11].

What is new in this research is to present, in an integrating manner, the sustainable actions which are specific to the company by "communicating sustainability". Starting from the values and rules that sustainability reporting and marketing use to obtain the company's sustainability, we will develop an index of the sustainability communication. It is an action that is supported by current approaches in business, requiring the need for more comprehensive information for stakeholders in order to gain their confidence in the future of the business. Thus, the regulators and those governing business management are covered by our research and invited to examine the features of the proposed index related to the sustainability communication.

In our view, sustainability communication represents the circulatory system of the economic entity, a very powerful and important center for business. It is its heart, having a functional half represented by sustainability reporting and the other half represented by sustainable marketing. It is the system that makes possible the transformation and evolution of the economic entity, in terms of its development and positioning as an important, involved and responsible social actor.

Communication is essential to anchor in the contemporary economic landscape and implicitly in society; moreover, it is effective [12]. Communication is becoming increasingly important, increasingly present and, we dare say, decisive for business. Allen, talking about communication, says "Communication plays a critical role within organizations generally. Organizing is first and foremost a communication activity. Communication occurs when sustainability-related issues are conceived, defined, discussed, planned, initiated within and between organizations, modofied, and, perhaps, terminated. It is present when various stakeholders encounter and react to the initiatives" [12]. Starting from this positioning, our view is that things are moved inside and outside the economic entity by actions of marketing and sustainability reporting.

This research has two directions of development. Firstly, we examine the existence of reporting and sustainability marketing in the companies listed on the Bucharest Stock Exchange (BSE) for the period 2008-2009, during the financial crisis. Secondly, we analyze whether there is a correlation between the company's future performance and the sustainability communication index. The regression analysis 
emphasizes the positive influence of the index of sustainability communication on the share price. The model explains $95.6 \%$ the dependent variable for 2008-2009 (92.8\% for 2008 and $98.4 \%$ for 2009 ).

The paper is structured as follows. In the first part, based on the literature review, characteristics of reporting and marketing are presented in terms of sustainability. In the second part, we present the sample and research methodology. In the last part, we analyzed the results and presented findings of the research.

\subsection{Sustainability Reporting and Sustainable Business Marketing}

The Annual Report of corporations turned into a marketing and public relations document [13]. If until recently, the financial accounting perspective has been the most important, considering that it reveals information on financing, on performance indicators for different user groups (ethnic minorities, people with disabilities, young people and local communities), on the audit and reporting, lately it seems that the marketing perspective gives a clear picture for those interested in the company's activity on pricing strategy, brand, online communication (including social networking and viral marketing), all engaging and presenting the company as an actor who is aware of the social and environmental approach that it should have [14].

Until recently, the financial information seems to lose ground. Researchers, regulators, and practitioners wonder whether the information provided in the financial statements meets all the expectations of external users $[15,16]$. The traditional financial and accounting information receives additional non-financial information necessary to provide greater transparency on the company as a whole [16]. This non-financial information is presented in sustainability reports, in social responsibility reports, or annual report [17]. What happens to the increasingly growing demand of investors and market analysts regarding the risks, impact, and sustainable performance of the company, confirms the need for a different approach.

Companies become aware of the need for another type of reporting approach and present ethical practices and corporate governance to potential investors, which leads to a better positioning on capital markets [18]. Thus, understanding the importance of presenting all these types of information, leading companies have resorted to the practice of their integration into a comprehensive report which presents both financial and non-financial information [19]. As such, worldwide companies prepare and present sustainability reports to external users. Although one may consider them as being similar from one company to another, there are differences due to the economic, social, or legal reasons, every company taking into account the needs of different users of the information that is presented when such reports are done.

The report entitled Sustainability for Tomorrow's Consumer of World Forum's Consumer Industries Community (World Economic Forum, 2009) [20], presents the directions to be considered when talking about sustainability:

- "Understanding the implications that the consumption growth and resource volatility have on cost structures and business models and determining the need for innovation;

- Exploiting the great discoveries made through innovation on life cycle and ensuring a sustainable cost to the consumer;

- Ensuring the impact of future sustainability developments by involving stakeholders such as investors and regulators."

Social responsibility follows the overall dynamics of international management trends, being standardized in the packages which can be implemented such as the UN Global Compact, The Global Reporting Initiative (GRI), and the ISO standards [21]. GRI's aim is to harmonize the various existing reporting systems and to provide a platform for an active dialogue about what sustainable performance is. Its model was the US financial reporting system FASB, which GRI sought to extend [22]: everywhere (globally), purpose (social, economic, and environmental performance indicators), flexibility (descriptive and quantitative indicators) and in terms of stakeholders (industry, 
financial sector, accounting profession, civil society, NGOs working in the field of human rights, and environment and other stakeholders).

Regarding the potential impact of the multiple dimensions of sustainability [23], sustainability marketing literature provides a theoretical discourse from the perspective of conceptual developing and practical formalization: from green marketing to sustainability marketing, in which the marketing actions propose remedies for social and environmental problems and no longer support their perpetuation.

In the 1970s, the ecological aspect represented a new paradigm in marketing strategy, and later on the social issues drew the attention of professionals [24]. Careful reassessment of the "green" or environmental factors in marketing strategy, as well as the new questioning of sustainability, as integrative ideas in the current marketing strategy, represents an interest for researchers.

Marketing research on sustainability is related to environmental and social aspects of sustainability, being presented in terms of green marketing or social marketing. To complete the picture about sustainability marketing, we present as relevant the results of the researches conducted by Chabowski, Mena, and Gonzalez-Padron [25] on the main directions of research in marketing. They offered a typology of sustainability capabilities that rank resources in terms of their concentration (internal versus external), importance (social versus environment), and intention (discretionary, ethical, legal) and suggested that sustainable initiatives can have influence on marketing assets.

The theory of the "triple bottom line" presents a further focus on the economy, the idea of highlighting the financial benefits that are generated by sustainability. In connection with the "triple bottom line", the company must conduct its business in connection with the environmental protection and by assuming the role of a socially-involved actor, aiming, at the same time, to obtain profit [26,27]. Thus, in building and highlighting the features of sustainability communication, we will consider, in addition to the stakeholders' theory, the "triple bottom line" theory in terms of social, environmental, and economic values which it shares.

For a company to be sustainable, radical changes are needed in all company departments, including research and development department, the production department, the accounting-finance department and marketing department [28]. Companies must implement sustainability practices in these compartments in order to obtain synergistic effects and revenue maximization. They are able to obtain a competitive advantage by publishing information about these practices. Reporting these activities and results to stakeholders is a role of marketing, even if it is done by sustainability reports, Corporate Social Responsibility (CSR) reports, or by other means of communication [29].

The motivation for such research comes both from what the literature reveals: the importance of sustainability reports and marketing for business sustainability, and especially from showing that the performance pursued by the company can be achieved by sustainability communication. We also offer an answer for those who wonder whether such practices bring added value to the company and we hope that the obtained results will convince them.

\subsection{Reporting and Sustainable Business Marketing in Terms of Performance}

The rapid adoption of sustainability reports by companies has been very well documented over the last decades [30,31]. Although these studies show there is no link between the increasing volume of disclosed information and the improvement of the company's performance, recent studies show a positive association between environmental reporting and environmental performance [32,33].

In the literature, we have studies showing a positive association between the amount of information in sustainability reports and the "quoted" status of the company [34], with direct involvement on performance. There are studies that show that the initiatives of CSR positively argue the correlation of the company's development with the customers' increasing availability for the products of the company, with the one of the potential employees to work for the company and not least with the one of the investors to invest in the company [35]. Furthermore, Luo and Bhattacharya's (2006) [36] study on the financial impact of CSR initiatives highlighted the positive effect on customers and thereby on the market value of the company. 
Thus, a positioning related by Allen: "Keegan Eisenstadt, of ClearSky Climate Solutions, described how, when he returns to companies he has previously worked with, management says that the greatest benefit they received from entering into a sustainability process is they found many other ways to increase their company efficiency: The process started with a review of their greenhouse gas footprint and then along the way they recognized, "Oh my gosh, we can save money on water, we can save money on power, we can save money on heating and cooling, we can save money by telecommuting or having video conferences", and they have found huge financial savings from efficiency gains just because somebody said, "Let's look'... They are saving tens of thousands to millions of dollars, depending on the client, from the efficiency gains, from thinking about the way they schedule employees, the way they schedule shifts, the way they bring in inputs, the way they manage supply chains and inventory, the way they market. It may not be that in the corporate suite they have a cleaner conscience, it's that they are amazed that being smart throughout their business could save them so much money" [12], becomes suggestive and highlights the importance of sustainability for a company.

Corporate social responsibility is related to the improvement of the company's financial results, showing the positive influence of CSR on market capitalization value [37]. The corporate social performance, the performance achieved by CSR in the competitive environment, has a negative effect on the risk of disinvestment [38]. Recent studies have shown how CSR negatively relates with the cost of capital [39], especially for the companies that operate in industries facing environmental problems.

Environmental sustainability has been the subject of research in relation to its impact on the company's performance. Companies reporting superior environmental performance enjoy a higher profitability, expressed by higher ROA, this effect being increased for companies operating in industries with a high degree of development [40].

Stakeholders have shown that they play an important role in shaping the company's sustainability actions. Environmental characteristics and attitudes of the communities in which companies operate have an impact on environmental performance [41], while pressures from external stakeholders may even affect environmental policy decisions regarding global standardization in multinationals [42]. In addition, different levels of environmental commitment-referred to as proactive, accommodation, defensive, and reactive-are associated with the relatively different importance of groups of stakeholders [43].

In this study, starting from the relevance of accounting information model, based on the association of the share price of action with the elements of the balance sheet [44] and profit and loss account [45], basically using a mixed model $[46,47]$, we show the influence of the sustainability communication index on share price.

\section{Experimental Section}

\subsection{Data Collection}

To build the research sample we considered the companies traded on the BSE and which operate in industry branches that are the most exposed from the social and environmental point of view. Thus, in order to test the sustainability communication index, we chose the manufacturing companies listed during 2008-2009, the period of the global financial crisis. On the BSE, at the time of data collection in June 2011, a total of 104 companies were traded. From these were eliminated the service companies (15), financial institutions (13), those which were unlisted (16), and the companies that did not disclose performance information necessary for this study (16). In the end we had a sample of 44 companies. The performance of companies transmits a normal situation that we can meet in the national economy in a period (2008) in which the economic activity was not affected by adverse events related to the market affected by the financial crisis (2009).

\subsection{Sustainability Communication Index (SCI)}

To build the sustainability communication index, we chose a number of 15 items (Table 1) from the Sustainability Reporting Guidelines, Version 3.0 (which operated in 2008-2009) [48]. All these 
items are related with marketing and reporting procedures. The information needed for the analysis of these 15 items was collected from documents and reports submitted by companies in their annual reports, sustainability reports and other documents presented on the company site. The items of the coverage degree used for calculation of SCI (expressed as a percentage) was determined based on the level of company's disclosed information.

Table 1. SCI items and their coverage degree.

\begin{tabular}{|c|c|c|c|}
\hline Item No. & Items & 2008 & 2009 \\
\hline 1 . & Consumer health and safety & $56.82 \%$ & $52.27 \%$ \\
\hline 2 . & Presentation of the main brands and products & $70.45 \%$ & $75 \%$ \\
\hline 3 . & The existence of a structure responsible for marketing communication & $43.18 \%$ & $47.73 \%$ \\
\hline 4 . & Using interactive media for marketing communication & $40.91 \%$ & $45.45 \%$ \\
\hline 5. & Description of activity impact, risks and opportunities & $84.09 \%$ & $88.64 \%$ \\
\hline 6. & $\begin{array}{l}\text { The need to adhere to laws, standards and codes related to } \\
\text { marketing communications }\end{array}$ & $36.36 \%$ & $38.64 \%$ \\
\hline 7 . & The precautionary principle is addressed by the company & $43.18 \%$ & $72.72 \%$ \\
\hline 8 . & Involvement in sponsorship & $38.64 \%$ & $31.82 \%$ \\
\hline 9. & Presentation of the company's stakeholders & $81.82 \%$ & $88.64 \%$ \\
\hline 10. & Problems with stakeholders and their resolution & $86.36 \%$ & $90.91 \%$ \\
\hline 11. & Initiatives to reduce energy consumption & $59.09 \%$ & $77.27 \%$ \\
\hline 12. & Initiatives to reduce water consumption & $34.09 \%$ & $47.73 \%$ \\
\hline 13. & Initiatives to reduce greenhouse gas & $56.82 \%$ & $63.64 \%$ \\
\hline 14. & Information on the structure of labor & $100 \%$ & $100 \%$ \\
\hline 15. & Programs and practices for local communities & $50 \%$ & $45,45 \%$ \\
\hline
\end{tabular}

The collection was made by two different researchers and their results were characterized by very small differences. Any disagreements were reconciled through discussion [49]. Analyzing the data presented in the Table 2 we can see that we are dealing with scores exceeding $80 \%$ regarding presentation of the items by the companies. To avoid bias of the final results of research these have to be removed [50]. The presentation reveals that once with the deepening crisis, companies become more responsible and manage to find the best solutions to maintain their activity.

Table 2. Descriptive statistics of the variables.

\begin{tabular}{cccccc}
\hline \multicolumn{5}{c}{ Descriptive Statistics of the Variables for 2008-2009 } \\
\hline Variables & Mean & Dev. Std. & Minim & Median & Maxim \\
\hline PRICE & 1.512 & 5.136 & 0.013 & 0.270 & 37.000 \\
EQUITY & 5.957 & 26.211 & -1.341 & 0.531 & 173.449 \\
EPS & 0.075 & 0.880 & -1.204 & 0.007 & 7.797 \\
SCI & 5.636 & 2.177 & 1.000 & 5.000 & 11.000 \\
TA & 8.223 & 32.823 & 0.106 & 1.061 & 220.562 \\
\hline \multicolumn{7}{c}{ Descriptive Statistics of the Variables for 2008 } \\
\hline Variables & Mean & Dev. Std. & Minim & Median & Maxim \\
\hline PRICE & 1.504 & 4.708 & 0.013 & 0.248 & 30.000 \\
EQUITY & 6.088 & 26.500 & -0.732 & 0.563 & 173.449 \\
EPS & 0.189 & 1.209 & -0.716 & 0.010 & 7.797 \\
SCI & 5.295 & 2.257 & 1.000 & 5.000 & 11.000 \\
TA & 8.586 & 33.951 & 0.129 & 1.137 & 220.562 \\
\hline \multicolumn{7}{c}{ Descriptive Statistics of the Variables for 2009 } & \\
\hline Variables & Mean & Dev. Std. & Minim & Median & Maxim \\
\hline PRICE & 1.520 & 5.587 & 0.018 & 0.289 & 37.000 \\
EQUITY & 5.825 & 26.225 & -1.341 & 0.520 & 173.189 \\
EPS & -0.037 & 0.280 & -1.204 & 0.006 & 0.657 \\
SCI & 5.977 & 2.062 & 3.000 & 5.500 & 11.000 \\
TA & 7.859 & 32.042 & 0.106 & 0.946 & 210.651 \\
\hline
\end{tabular}


The relevance of such an index depends on the objectivity of criteria underlying its construction. Measurement of sustainability communication based on content analysis methodology provides and ensures objectivity for the proposed approach [33,51]. Through content analysis of the company's documents and reports, we selected and scored for each of the remaining 11 items a score, using the criterion of "yes $/$ no" or " $1 / 0$ ". To reduce the degree of subjectivity in the index calculation, the elements had an equal value in the final composition of the index [52]. Then, the scores given for each item presented were gathered and, thus, a total was obtained, which is the sustainability communication index. The maximum value of the index for the company is 11 .

\subsection{The Model}

To highlight the influence that the communication sustainability index has on the company's performance we will use the "price model", based on its proved relevance regarding the future performance $[46,47]$. It is a model that shows the future performance of the company as a linear function of the equity book value and of the present value of future incomes. The model which we use in the analysis of this study is well suited to capital markets and is susceptible to be used for a finite number of times, which makes it suitable for our analysis for 2008 and 2009. At the price model we added sustainability communication index (SCI) as independent variables (Model (1)). In order to test the price model, we added total assets as a measure of company size (Model (2)).

$$
\text { PRICE } E_{t, i}=\beta_{0}+\beta_{1} E Q U I T Y_{t, i}+\beta_{2} E P S_{t, i}+\beta_{3} S C I_{t, i}+\varepsilon_{t, i}
$$

where:

- $\quad$ PRICE $E_{t, i}$-share price for the year $t$ of the company $i$;

- $\quad E Q U I T Y_{t, i}$-book value of equity per share for the year $t$ of the company $i$;

- $E P S_{t, i}$-annual earnings per share for the year $t$ of the company $i$;

- $S C I_{t, i}$-sustainability communication index for the year $t$ of the company $i$.

$$
\text { PRICE } E_{t, i}=\beta_{0}+\beta_{1} \text { EQUITY }_{t, i}+\beta_{2} E P S_{t, i}+\beta_{3} S C I_{t, i}+\beta_{4} T A_{t, i}+\varepsilon_{t, i}
$$

where $T A_{t, i}$ are the total assets per share for the year $t$ of the company $i$;

\section{Results and Discussion}

\subsection{Descriptive Statistics}

Descriptive statistics are disclosed for the variables used in the model for 2008-2009 (Table 2).

According to descriptive statistics, the communication of companies traded on the BSE is deficient in 2008 (the median has a value below the threshold of 5.5), the companies overcoming these deficiencies in 2009. One can see an improvement in the quality of communication, which means that companies' awareness grew up during the crisis and realized that stakeholders need to know who you really are. Information that we have from this statistic is related to large scattering data, which explains the economic context and the actions taken by Romanian companies on sustainability communication.

It is a highly volatile situation on the performance of listed and traded companies during financial crisis. The sample of listed companies is very small, which means that we must give up eliminating some extreme values. Although being aware that we could have obtained better results, we accept this risk in favor of keeping a sample of more than 30 observations, in order to enter the rigors of what it means for regression analysis.

\subsection{Analyzing the Influence of SCI on the Future Performance of Companies Listed on the BSE}

The estimates obtained by performing the regression analysis for coefficients and t-statistic for dependent and independent variables, as well as for Adjusted $R^{2}$ and F. Significant values are presented in Table 3. Based on the F test, the model was validated. For all periods, the coefficients of 
communication sustainability index are positive and significant at $0.01,0.10$, and 0.05 , respectively, which show the positive linear influence that SCI has on the share price.

Table 3. Coefficient analysis.

\begin{tabular}{|c|c|c|c|c|c|c|c|}
\hline \multicolumn{8}{|c|}{$P R I C E_{t, i}=\beta_{0}+\beta_{1} E Q U I T Y_{t, i}+\beta_{2} E P S_{t, i}+\beta_{3} S C I_{t, i}+\varepsilon_{t, i}($ Model 1) } \\
\hline Year & $\mathbf{N}$ & EQUITY & EPS & SCI & Adjusted & & Sig.F \\
\hline $2008 / 2009$ & 88 & $0.207(33.216) * * *$ & $-0.633(-3.428) * * *$ & $0.144(2.688) * * *$ & 0.956 & & 0.000 \\
\hline 2009 & 44 & $0.209(49.359) * * *$ & $1.130(2.875)^{* * *}$ & $0.117(2.239) * *$ & 0.984 & & 0.000 \\
\hline \multicolumn{8}{|c|}{ PRICE $E_{t, i}=\beta_{0}+\beta_{1}$ EQUITY $_{t, i}+\beta_{2} E P S_{t, i}+\beta_{3} S C I_{t, i}+\beta_{4} T A_{t, i}+\varepsilon_{t, i}($ Model 2) } \\
\hline $2008 / 2009$ & 88 & $0.390(6.266)^{* * *}$ & $-0.627(-3.549) * * *$ & $0.139(2.705) * * *$ & $-0.146(-2.951) * * *$ & 0.959 & 0.000 \\
\hline 2008 & 44 & $0.461(2.433) * * *$ & $-1.008(-1.194)$ & $0.184(2.167) *$ & $-0.191(-1.518)$ & 0.931 & 0.000 \\
\hline 2009 & 44 & 0.129 (1.457) & $1.475(0.010) * * *$ & $0.121(2.293)^{* *}$ & $0.066(0.917)$ & 0.984 & 0.000 \\
\hline
\end{tabular}

PRICE: share price; EQUITY: equity per share; EPS: earnings per share; SCI: sustainability communication index, TA: total assets; ${ }^{*}, * * * *$ significant at $0.10,0.05,0.01$.

By analyzing the coefficients and their integration into different classes of significance, we have a picture of what happened in the Romanian business. Throughout the period, 2008-2009, the sustainability communication index has the strongest coefficient $(0.144)$ and the best fit to the class of significance (0.01). 2009 follows with a coefficient of 0.117; the coefficient is lower than the one obtained for 2008, but with a significance of 0.05 which suggests it detrimental to the index for 2008 (it has been pushed back for the same reasons by the coefficient for 2008-2009). The results obtained are consistent with the results of other studies that have shown how sustainability practices adopted by companies for managing their operations are highly correlated with indicators of competitiveness and performance [53,54]. Including total assets in the price model as an independent variable increases the $R^{2}$ from 0.956 to 0.959 for the period 2008-2009 and from 0.928 to 0.931 for 2008, shows that the share price is influenced by company size.

In order to see if the sustainability communication is influenced by the company size we realized a correlation analysis between SCI, on the one hand, and total assets, on the other hand. The very little correlation coefficient $(-0.10)$ suggests that sustainability communication is not influenced by the size of the company.

Therefore, we consider that the results place us in a position different from that of Pava and Krausz, cited in Salzmann, Ionescu-Somers and Steger, 2005 [2]: “The 'overwhelming preponderance' of evidence indicating that good ESP is associated with good FP does not convince sceptics, since results are subject to research bias, exhibit great variation and are ambiguous regarding the causal relationship between the two concepts".

The research we propose here is much more applicable to the already satisfied needs of the economic entity regarding the idea of sustainable business. Our view is that accounting and financial reporting and marketing communications, united by what we have called sustainable communication, are responsible for this. Thus, taking into account the notion of "green" (representing the combination of symbolic and substantive actions, where the firm discusses environmental responsibility in terms of what they are doing currently or have done (substantive action), and what they plan to do in the future (symbolic action)), [55], we refer, in our paper, to what the company applies, practically to a new framework for doing business in a sustainable way; it is an approach that conveys a different perspective (the combined action of the two functions of the company, the marketing and the financial accounting function), which distinguishes this paper in the literature.

\section{Conclusions}

The results showed that the sustainability communication index influences the share price, confirming researches that use the same model as the one analyzed in this study [56,57]. The approach of presenting the communication of sustainability-performance relationship can be seen as a much 
more direct way which supports and accepts the SSP (Strategy, Structure, and Performance) paradigm, that is the company's strategy must be supported by the structure and must lead to performance [7]. It is another central key with which the whole, which we discussed in connection with the company's business, can be understood. Thus, the sustainable business must have a structure (based, we believe, among others, on marketing and sustainability reporting) and tools to assess the impact of structure on company's performance (sustainability communication index proposed in this research).

The results confirm the statement "Thus, taken together, empirical evidence suggests that environmental and financial performances are positively linked" [55], thus being an approach that offers a perspective different from the one of the authors mentioned above (contrary to our hypothesis, substantive actions were not related to increased financial performance. In contrast, and consistent with our hypothesis, symbolic actions were related to decreased financial performance). Our results confirm the link between sustainability communication and financial performance.

Companies promoting business in accordance with the principles of sustainability have become a hot spot in the global economy. Highlighting a guideline that is planned, integrated, and appropriately coordinated towards environmental protection, being involved in the local communities' initiatives or supporting one's own business and its long-term effectiveness, are the key elements by which a business can achieve a harmonious development in time, a synergistic development and even a competitive advantage.

Sustainable businesses require a sustainable marketing concept, by which all stakeholders are required to change their mindset. This claims an understanding of a business in a holistic way, which involves partnership cooperation of all the stakeholders. Furthermore, one has to take into account that this guideline requires the attraction of partners with a motivation, not always an exclusively economic one (local communities, civil society, government bodies, and NGOs).

This research contributes to the promotion of concepts that were little discussed in the literature of our country, and by the scientific contribution which is certain due to our results (statistical coefficients with high degrees of values and accuracy) representing something unique in the field of economic research and a very difficult state to be achieved by other surveys of marketing and sustainable business reporting.

The limitations of this study are given by the relatively small sample of observations, by possible errors in reporting that were made by companies throughout the financial crisis and by betting, probably, on the elements that are not the most representative when discussing the communication that a sustainable company must do. Although we treated the correlation, it must be said that ambiguity still hovers around it, although if we relate to other studies in the literature, the fact that a company is listed protects that data [55].

Despite these limitations, it must be said that the results are relevant to the effect of sustainability communication on the future performance of companies, which means that it can and has to serve as an object of analysis for those interested in the value of companies listed on stock exchanges and that a further natural continuation could be represented by the checking of the proposed model (both the index and the testing model) on a stock that is not affected by these problems of information asymmetry.

We think that next statement is very expressive and relevant for our research: "If you learn of training about sustainability, investigate it; if you like what you see, invite others to attend" [12]. Therefore, we invite to such approach and regarding the present research, our vision is that every content, every idea should arouse interest, require reflection, and substantiate the acceptance or change efforts from those interested to take things further.

Acknowledgments: We are grateful to two anonymous reviewers for their helpful comments and suggestions. The comments of Marcel Ausloos, (University of Leicester) and Claudiu Herteliu (The Bucharest University of Economic Studies) are greatly appreciated.

Author Contributions: The authors of this article have equally contributed to every stage in its development.

Conflicts of Interest: The authors declare no conflict of interest. 


\section{References}

1. Echeverri, P.; Skalen, P. Cocreation and codestruction: A practice-theory based study of interactive value formation. Market. Theory 2011, 11, 351-373. [CrossRef]

2. Salzmann, O.; Ionescu-Somers, A.; Steger, U. The business case for corporate sustainability: Literature review and research options. Eur. Manag. J. 2005, 23, 27-36. [CrossRef]

3. Bebington, J.; Larringa, C. Accounting and sustainable development: An exploration. Account. Organ. Soc. 2014, 39, 395-413. [CrossRef]

4. Gray, R. The social accounting project and accounting organizations and society privileging engagement, imaginings, new accountings and pragmatism over critique? Account. Organ. Soc. 2002, 27, 687-708. [CrossRef]

5. Gray, R. Is accounting for sustainability actually accounting for sustainability... and how would we know? An exploration of narratives of organisation and the planet. Account. Organ. Soc. 2010, 35, 47-62. [CrossRef]

6. Dyllick, T.; Hockerts, K. Beyond the business case for corporate sustainability. Bus. Strategy Environ. 2002, 11, 130-141. [CrossRef]

7. Chandler, A.D., Jr. Strategy and Structure: Chapters in the History of the Industrial Enterprise; The MIT Press: Cambridge, MA, USA, 1962.

8. United Nations. World Commission on Environment and Development. 1987. Available online: http:/ / www.un-documents.net/wced-ocf.htm (accessed on 5 May 2015).

9. Ketola, T. A holistic corporate responsibility model: Integrating values, discourses and actions. J. Bus. Eth. 2008, 80, 419-435. [CrossRef]

10. Krajnc, D.; Glavic, P. How to compare companies on relevant dimensions of sustainability. Ecol. Econ. 2005, 55, 551-563. [CrossRef]

11. Philippe, D.; Durand, R. The impact of norm-conforming behaviors on firm reputation. Strateg. Manag. J. 2011, 32, 969-993. [CrossRef]

12. Allen, M. Strategic Communication for Sustainable Organizations: Theory and Practice; Springer: Berlin, Gemany, 2016.

13. McKinstry, S. Designing the annual reports of Burton Plc from 1930 to 1994. Account. Organ. Soc. 1999, 21, 89-111. [CrossRef]

14. Campbell, D.; McPhail, K.; Slack, R. Face work in annual reports-A study of the management of encounter through annual reports, informed by Levinas and Bauman. Account. Audit. Account. J. 2009, 22, 907-932.

15. Adams, S.; Fries, J.; Simnett, R. The Journey Toward Integrated Reporting. Account. Dig. 2011, 558, 1-41.

16. Cohen, J.; Holder-Webb, L.L.; Nath, L.; Wood, D. Corporate Reporting on Nonfinancial Leading Indicators of Economic Performance and Sustainability. Account. Horiz. 2012, 26, 65-90. [CrossRef]

17. Simnett, R.; Vanstraelen, A.; Chua, W.F. Assurance on Sustainability Reports: An International Comparison. Account. Rev. 2009, 84, 937-968. [CrossRef]

18. Grewal, R.; Chandrashekaran, M.; Citrin, A.V. Customer satisfaction heterogeneity and shareholder value. J. Market. Res. 2010, 47, 612-626. [CrossRef]

19. Eccles, R.G.; Kruz, M.P. One Report_Integrated Reporting for a Sustainable Society; John Wiley \& Sons Inc.: Hoboken, NJ, USA, 2010.

20. World Economic Forum. Sustainability for Tomorrow's Consumer. 2009. Available online: http://www3.weforum.org/ docs/WEF_CI_SustainabilityForTomorrowsConsumer_Report_2009.pdf (accessed on 12 May 2015).

21. Sahlin-Andersson, K. Corporate social responsibility: A trend and a movement, but of what and for what? Corp. Gov. 2006, 6, 595-608. [CrossRef]

22. Brown, H.S.; de Jong, M.; Levy, D.L. Building institutions based on information disclosure: Lessons from GRI's sustainability reporting. J. Clean. Prod. 2009, 17, 571-580. [CrossRef]

23. Cronin, J.J.; Smith, J.S.; Gleim, M.R.; Ramirez, E.; Martinez, J.D. Green marketing strategies: An examination of stakeholders and the opportunities they present. J. Acad. Market. Sci. 2011, 39, 158-174. [CrossRef]

24. Kumar, V.; Rahman, Z.; Kazmi, A.A.; Goyal, P. Evolution of sustainability as marketing strategy: Beginning of new era. Proced. Soc. Behav. Sci. 2012, 37, 482-489. [CrossRef]

25. Chabowski, B.R.; Mena, J.A.; Gonzalez-Padron, T.L. The structure of sustainability research in marketing, 1958-2008: A basis for future research opportunities. J. Acad. Market. Sci. 2011, 39, 55-70. [CrossRef] 
26. Elkington, J. Cannibals with Forks: The Triple Bottom Line of 21st Century Business; New Society: Stony Creek, CT, USA, 1998.

27. Savitz, A.W.; Weber, K. The Triple Bottom Line: How Today's Best-Run Companies are Achieving Economic, Social and Environmental Success-And How You Can too; Jossey-Bass: San Francisco, CA, USA, 2006.

28. Kotler, P. Reinventing marketing to manage the environmental imperative. J. Market. 2011, 75, $132-135$. [CrossRef]

29. Nikolaeva, R.; Bicho, M. The role of institutional and reputational factors in the voluntary adoption of corporate social responsibility reporting standards. J. Acad. Market. Sci. 2011, 39, 136-157. [CrossRef]

30. Deegan, C.; Rankin, M.; Tobin, J. An examination of the corporate social and environmental disclosures of BHP from 1983-1997: A test of legitimacy. Account. Audit. Account. J. 2002, 15, 312-343. [CrossRef]

31. Gray, R.; Kouhy, R.; Lavers, S. Corporate social and environmental reporting. Account. Audit. Account. J. 1995, 8, 47-77. [CrossRef]

32. Al-Tuwaijri, S.A.; Christensen, T.E.; Hughes, K.E. The relations among environmental disclosure, environmental performance, and economic performance: A simultaneous equations approach. Account. Organ. Soc. 2004, 29, 447-471. [CrossRef]

33. Clarkson, P.M.; Li, Y.; Richardson, G.D.; Vasvari, F.P. Revisiting the relation between environmental performance and environmental disclosure: An empirical analysis. Account. Organ. Soc. 2008, 33, 303-327. [CrossRef]

34. Ahmed, K.; Courtis, J.K. Associations between corporate characteristics and disclosure levels in annual reports: A meta-analysis. Br. Account. Rev. 1999, 31, 35-61. [CrossRef]

35. Sen, S.; Bhattacharya, C.B.; Korschun, D. The role of corporate social responsibility in strengthening multiple stakeholder relationships: A field experiment. J. Acad. Market. Sci. 2006, 34, 158-166. [CrossRef]

36. Luo, X.; Bhattacharya, C.B. Corporate social responsibility, customer satisfaction, and market value. J. Market. 2006, 70, 1-18. [CrossRef]

37. Pätäri, S.; Jantunen, A.; Kyläheiko, K.; Sandström, J. Does sustainable development foster value creation? Empirical evidence from the global energy industry. Corp. Soc. Responsib. Environ. Manag. 2012, 19, 317-326. [CrossRef]

38. Luo, X.; Bhattacharya, C.B. The debate over doing good: Corporate social performance, strategic marketing levers, and firm-idiosyncratic risk. J. Market. 2009, 73, 198-213. [CrossRef]

39. Reverte, C. The impact of better corporate social responsibility disclosure on the cost of equity capital. Corp. Soc. Responsib. Environ. Manag. 2012, 19, 253-272. [CrossRef]

40. Russo, M.V.; Fouts, P.A. A resource-based perspective on corporate environmental performance and profitability. Acad. Manag. J. 1997, 40, 534-559. [CrossRef]

41. Kassinis, G.; Vafeas, N. Stakeholder pressures and environmental performance. Acad. Manag. J. 2006, 49, 145-159. [CrossRef]

42. Christmann, P. Multinational companies and the natural environment: Determinants of global environmental policy standardization. Acad. Manag. J. 2004, 47, 747-760. [CrossRef]

43. Henriques, I.; Sadorsky, P. The relationship between environmental commitment and managerial perceptions of stakeholder importance. Acad. Manag. J. 1999, 42, 87-99. [CrossRef]

44. Barth, M.E.; Beaver, W.H.; Landsman, W. Value relevance of banks fair value disclosures under SFAS No. 107. Account. Rev. 1996, 71, 513-537.

45. Dhaliwal, D.; Subramanyam, K.R.; Trezevant, R. Is comprehensive income superior to net income as a measure of firm performance? J. Account. Econ. 1999, 26, 43-67. [CrossRef]

46. Feltham, J.; Ohlson, J.A. Valuation and clean surplus accounting for operating and financial activities. Contemp. Account. Res. 1995, 11, 689-731. [CrossRef]

47. Ohlson, J.A. Earnings, book values, and dividends in security valuation. Contemp. Account. Res. 1995, 11, 161-182. [CrossRef]

48. Global Reporting Initiatives, Standards. 2015. Available online: https://www.globalreporting.org/standards (accessed on 5 May 2015).

49. Krippendorff, K. Content 120 Analysis: An Introduction to its Methodology, 3rd ed.; London SAGE: Los Angeles, CA, USA, 2013.

50. Guthrie, J.; Pang, T.T. Disclosure of goodwill impairment under AASB 136 from $2005-2010$. Aust. Account. Rev. 2013, 23, 216-231. [CrossRef] 
51. Cormier, D.; Magnan, M. The Revisited Contribution of Environmental Reporting to Investors' Valuation of a Firm's Earnings: An International Perspective. Ecol. Econ. 2007, 62, 613-626. [CrossRef]

52. Tsalavoutas, I.; Evans, L.; Smith, M. Comparison of two methods for measuring compliance with IFRS mandatory disclosure requirements. J. Appl. Account. Res. 2010, 11, 213-228. [CrossRef]

53. Bansal, P.; Clelland, I. Talking trash: Legitimacy, impression management, and unsystematic risk in the context of the natural environment. Acad. Manag. J. 2004, 47, 93-103. [CrossRef]

54. Jacobs, B.W.; Singhal, V.R.; Subramanian, R. An empirical investigation of environmental performance and the market value of the firm. J. Oper. Manag. 2010, 28, 430-441. [CrossRef]

55. Walker, K.; Wan, F. The harm of symbolic actions and greenwashing: Corporate actions and communications on environmental performance and their financial implications. J. Bus. Ethics 2012, 109, 227-242. [CrossRef]

56. Filip, A.; Raffournier, B. The value relevance of earnings in a transition economy: The case of Romania. Int. J. Account. 2010, 45, 77-103. [CrossRef]

57. Jianu, I.; Jianu, I.; Ileanu, B.V.; Nedelcu, M.V.; Herteliu, C. The value relevance of financial reporting in Romania. Econ. Comput. Econ. Cybern. Stud. Res. 2014, 48, 167-182.

(C) 2015 by the authors; licensee MDPI, Basel, Switzerland. This article is an open access article distributed under the terms and conditions of the Creative Commons by Attribution (CC-BY) license (http:/ / creativecommons.org/licenses/by/4.0/). 